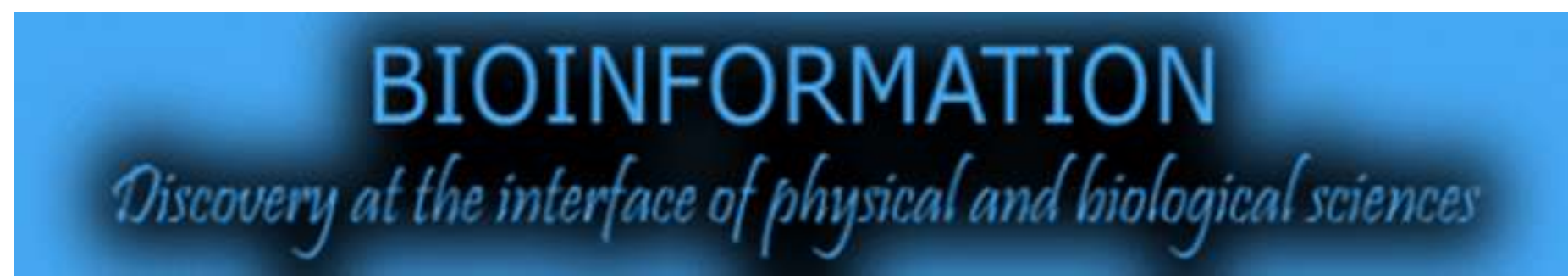

\title{
FCDD: A Database for Fruit Crops Diseases
}

\author{
Rupal Chauhan ${ }^{1 *}$, Yogesh Jasrai ${ }^{1}$, Himanshu Pandya1, Suman Chaudhari ${ }^{2} \&$ Chand Mal \\ Samota $^{3}$
}

${ }^{1}$ Applied Botany Centre, Department of Botany, University School of Sciences, Gujarat University, Ahmadabad 380009, Gujarat, India; ${ }^{2}$ Department of Plant Pathology, C.P. College of Agriculture, S.D. Agricultural University, Sardarkrushinagar, Dantiwada 385506, Gujarat, India; ${ }^{3}$ Department of Computer Science \& Engineering, College of Technology and Engineering, Maharana Pratap University of Agriculture and Technology, Udaipur, Rajasthan, India; Rupal Chauhan - Email: chauhanrupal757@gmail.com; ${ }^{*}$ Corresponding author

Received September 11, 2014; Accepted September 15, 2014; Published September 30, 2014

\begin{abstract}
:
Fruit Crops Diseases Database (FCDD) requires a number of biotechnology and bioinformatics tools. The FCDD is a unique bioinformatics resource that compiles information about 162 details on fruit crops diseases, diseases type, its causal organism, images, symptoms and their control. The FCDD contains 171 phytochemicals from 25 fruits, their $2 \mathrm{D}$ images and their 20 possible sequences. This information has been manually extracted and manually verified from numerous sources, including other electronic databases, textbooks and scientific journals. FCDD is fully searchable and supports extensive text search. The main focus of the FCDD is on providing possible information of fruit crops diseases, which will help in discovery of potential drugs from one of the common bioresource-fruits. The database was developed using MySQL. The database interface is developed in PHP, HTML and JAVA. FCDD is freely available.
\end{abstract}

Availability: http://www.fruitcropsdd.com/

Key words: Fruit crops, Diseases, Diseases type, Causal organism, Symptoms, Control, Database, Phytochemicals.

\section{Background:}

Fruits are good source of beneficial health effects, namely vitamins, minerals, trace elements, dietary fiber, proteins of vitamins. Here, we describe the development of a database containing information for fruit crops diseases improvement. Though a great deal of information has been acquired about fruit crops diseases, diseases type, its causal organism, images, symptoms, their control, possible sequences [1-2] and phytochemicals much of this information is highly dispersed and of limited accessibility, often being confined to specialized textbooks, obscure government documents or subscriptionrequiring scientific journals. Fortunately, over the past few years a number of web-accessible databases have started to appear, such as the pubchem and chembank phytochemical database and so on. They focus on providing information on ISSN 0973-2063 (online) 0973-8894 (print)

Bioinformation 10(9): 595-598 (2014) either chemical property, structure, ambiguous mode of action or only about the source of phytochemicals. A few databases were reported for biological applications, which are mostly focusing on particular aspects of dietary phytochemicals [3-4], which are based on experimental and published secondary data from the scientific reports. However, the lack information on fruit crops diseases, diseases type, its causal organism, images, symptoms, their control, phytochemicals. It is important to develop strategies to improve fruit crops diseases productivity. Fruit crop diseases improvement involves systematic monitoring of parameters essential for crop development. This could be achieved by developing databases containing information similar to many other crop databases [5-9]. This Fruit Crops Diseases Database (FCDD) was developed to be useful in finding effective chemical entities in drug discovery. 


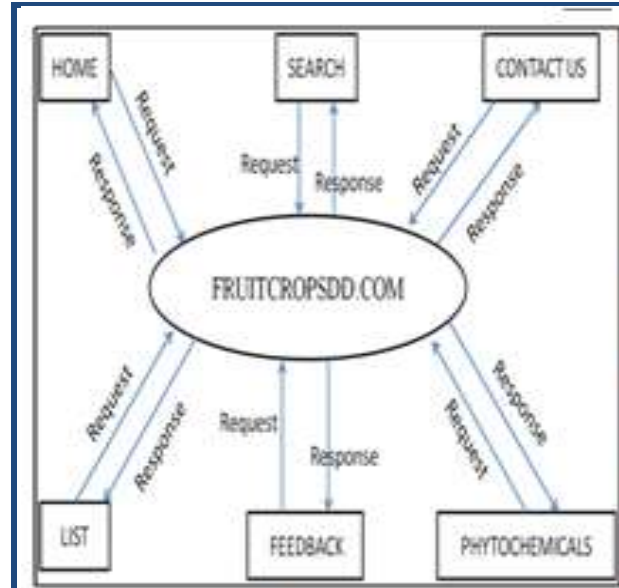

$\mathbf{A}$

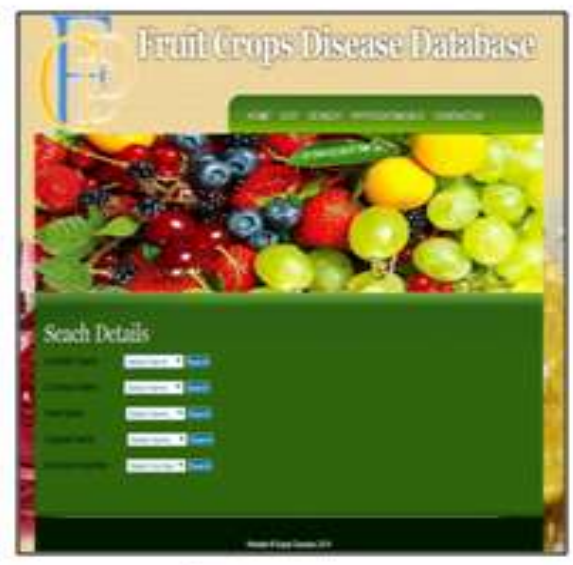

D

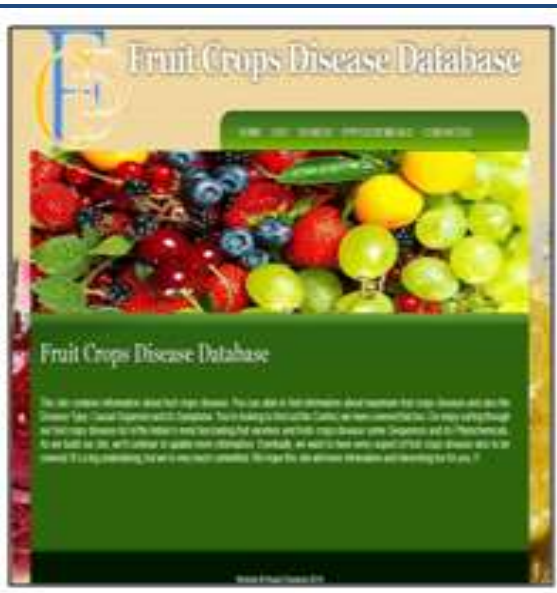

B

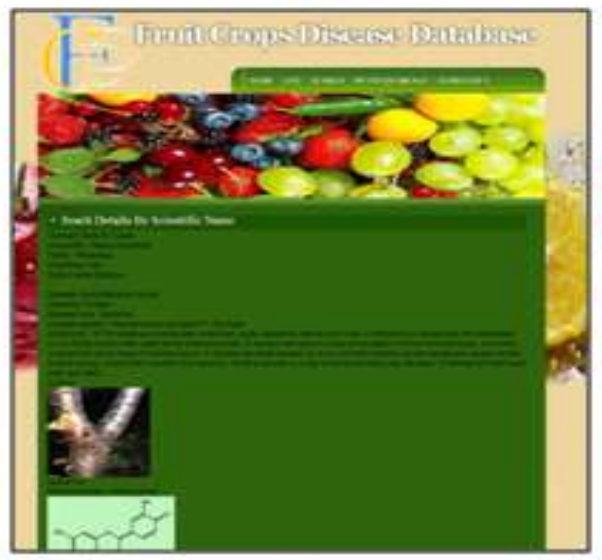

$\mathbf{E}$

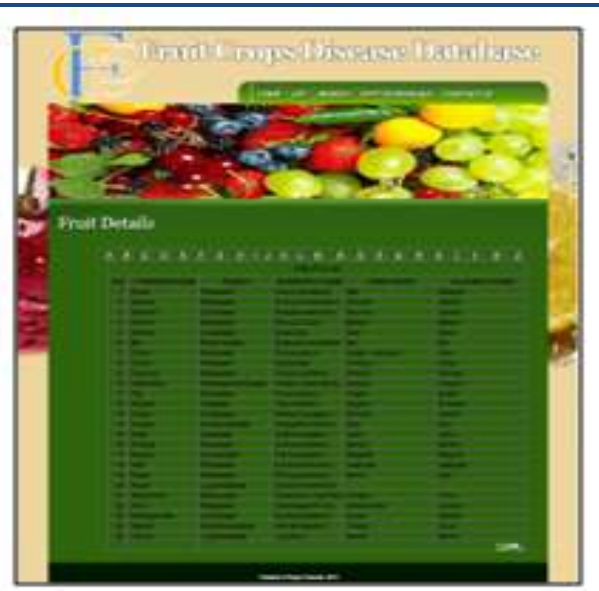

C

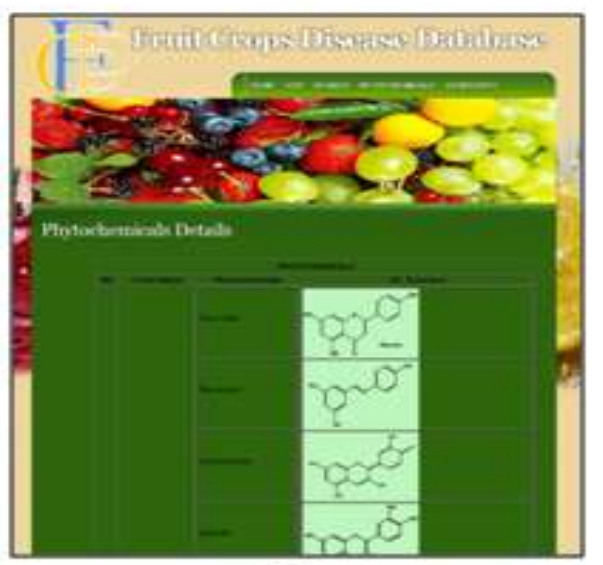

F

Figure 1: (A) Basic architecture of FCDD is shown; (B),(C),(D),(E),(F) A screen shot of the Fruit Crops Diseases Database (FCDD)

\section{Methodology:}

Data on fruit crops diseases, diseases type, its causal organism, images, symptoms, their control, phytochemicals, 2D images and their possible sequences were manually collected from online databases [1-4] and from peer-reviewed scientific articles and various literatures [5-9]. From 25 commonly consumed fruit crops in India, 162 details on fruit crops diseases, diseases type, its causal organism, images, symptoms, their control 171 phytochemicals, their 2D images and their 20 possible sequences were collected and this data was compiled using Microsoft Access ${ }^{\circledR}$. The 2D molecular structures as .sdf file of the phytochemicals were rendered from online small molecular databases namely, Pubchem and Chembank. Primary Table 1 (see supplementary material) consists of twelve data fields (fruit crops scientific name, family, common name, hindi name, gujarati name, phytochemical, sequences, diseases type, its causal organism, images, symptoms and their control). Finally, data were exported from Microsoft Access ${ }^{\circledR}$ to Microsoft SQL server, which is used as the web interface. The front end of the database was designed constructed using PHP, HTML and JAVA and can be accessed at http:/ / www.fruitcropsdd.com/.

\section{Utility to the biological community:}

The database finds utility in fruit crops diseases improvement. FCDD emphasizes the information of fruit crops diseases, diseases type, its causal organism, images, symptoms and their control. It contains phytochemicals from fruits, their 2D images and their possible sequences also. The database finds utility to the scientific community for a quick review on the number of fruit crops diseases and phytochemicals for diseases research and provides enormous scope for development of drugs. The database is freely available in public domain.

\section{Caveat and Future Developments:}

The database website has a provision for updating and adding new in future by the database manager. All data fields will be curates and then accepted by the built in program. Database will be extended for phytochemicals present in fruits.

\section{References:}

[1] http://www.ncbi.nlm.nih.gov/Genbank/

[2] http://www.uniprot.org/

[3] www.pubchem.ncbi.nlm.nih.gov

[4] www.chembank.broadinstitute.org

[5] Wheeler DL et al. Nucleic Acids Res. 2005 33(Database issue): D39

[6] Mishra DS et al. J Environ Biol. 2013 34: 183

[7] http://agricat.egranth.ac.in/cgi-bin/koha/opacdetail.pl?biblionumber $=89008 \&$ query_desc $=a$ au $\% 3$ AV.N. $\% 2$ OPathak 
[8] https://www.charoka.com/Diseases-of-HorticulturalCrops-Fruits/b/3266\#about_book
[9] http://www.worldcat.org/title/market-diseases-ofgrapes-and-other-small-fruits/oclc/755127105

\section{Edited by P Kangueane}

Citation: Chauhan et al. Bioinformation 10(9): 595-598 (2014)

License statement: This is an open-access article, which permits unrestricted use, distribution, and reproduction in any medium, for non-commercial purposes, provided the original author and source are credited 


\section{Supplementary material:}

Table 1: Categories of typical search terms of FCDD

\begin{tabular}{|c|c|c|c|}
\hline Search category & Query type & Search term & Example input \\
\hline Scientific Name & $\begin{array}{l}\text { Fruits scientific name and } \\
\text { diseases details }\end{array}$ & Scientific name of fruits & Malus domestica \\
\hline Common Name & $\begin{array}{l}\text { Fruits name and diseases } \\
\text { details }\end{array}$ & Common name of fruits & Apple \\
\hline Hindi Name & $\begin{array}{l}\text { Fruits hindi name and } \\
\text { diseases details }\end{array}$ & Hindi name of fruits & Seb \\
\hline Gujarati Name & $\begin{array}{l}\text { Fruits gujarati name and } \\
\text { diseases details }\end{array}$ & Gujarati name of fruits & Safarjan \\
\hline Accession Number & $\begin{array}{l}\text { Possible fruit diseases } \\
\text { sequences }\end{array}$ & $\begin{array}{l}\text { Accession number of } \\
\text { sequences }\end{array}$ & E7EM08 \\
\hline
\end{tabular}

